\title{
Isolation of sulfate-reducing bacteria from Tunisian marine sediments and description of Desulfovibrio bizertensis sp. nov.
}

\author{
Olfa Haouari, ${ }^{1,2}$ Marie-Laure Fardeau, ${ }^{1}$ Laurence Casalot, ${ }^{1}$ \\ Jean-Luc Tholozan, ${ }^{1}$ Moktar $\mathrm{Hamdi}^{2}$ and Bernard Ollivier ${ }^{1}$ \\ ${ }^{1}$ Laboratoire de microbiologie IRD, UMR 180, IFR-BAIM, Universités de Provence et de la \\ Méditerranée, ESIL case 925, 163 Avenue de Luminy, F-13288 Marseille cedex 09, France \\ ²UR-Procédés Microbiologiques et Alimentaires, INSAT, 1080 Tunis, Tunisia
}

Correspondence

Bernard Ollivier

ollivier@esil.univ-mrs.fr
In marine ecosystems, sulfate-reducing bacteria (SRB) contribute significantly $(50 \%)$ to the mineralization of organic matter (Jørgensen, 1982). Hydrogenotrophic SRB of the family Desulfovibrionaceae within the Deltaproteobacteria have been found as common inhabitants of these ecosystems (Jørgensen \& Bak, 1991; Widdel \& Hansen, 1992). Within the Desulfovibrionaceae, many marine Desulfovibrio species have been isolated. They include Desulfovibrio acrylicus (van der Maarel et al., 1996), D. africanus (Campbell et al., 1966), D. giganteus (Esnault et al., 1988), D. gigas (Le Gall, 1963) and D. inopinatus (Reichenbecher \& Schink, 1997), all recovered from shallow marine ecosystems, and D. profundus (Bale et al., 1997) and D. hydrothermalis (Alazard et al., 2003) recovered from deep marine environments.

We have undertaken microbiological studies to isolate, in particular, hydrogenotrophic SRB from various marine sediments recovered near Tunis, Korbous and Bizerte, Tunisia. In addition to hydrogen, peptone and yeast extract were also used as energy sources in the presence of sulfate as

Abbreviation: SRB, sulfate-reducing bacteria.

The GenBank/EMBL/DDBJ accession number for the 16S rRNA gene sequence of strain $\mathrm{MB}^{\top}{ }^{\top}$ is $\mathrm{DQ} 422859$. the terminal electron acceptor. Using these cultures, we isolated only members of the genus Desulfovibrio. One of these organisms, designated strain $\mathrm{MB}^{\mathrm{T}}$, is suggested to represent a novel species of the genus Desulfovibrio.

Sediment samples were collected in sterile plastic bottles from the sea off Korbous, Tunis and Bizerte, and kept at $5{ }^{\circ} \mathrm{C}$ until inoculation. The in situ temperature, $\mathrm{pH}$ and conductivity of samples were $30^{\circ} \mathrm{C}, 7 \cdot 8$ and $62 \mathrm{mS} \mathrm{cm}{ }^{-1}$, respectively.

The Hungate technique (Hungate, 1969) was then used throughout for cultivation. The basal medium contained (per litre of distilled water): $0.3 \mathrm{~g} \mathrm{KH}_{2} \mathrm{PO}_{4}, 0.3 \mathrm{~g} \mathrm{~K}_{2} \mathrm{HPO}_{4}$, $1.0 \mathrm{~g} \mathrm{NH}_{4} \mathrm{Cl}, 23 \mathrm{~g} \mathrm{NaCl}, 3 \mathrm{~g} \mathrm{Na}_{2} \mathrm{SO}_{4}, 0.1 \mathrm{~g} \mathrm{KCl}, 0 \cdot 1 \mathrm{~g}$ $\mathrm{CaCl}_{2} \cdot 2 \mathrm{H}_{2} \mathrm{O}, 0.1 \mathrm{~g}$ yeast extract (Difco), $0.5 \mathrm{~g}$ cysteine hydrochloride, $1 \mathrm{ml}$ trace mineral element solution (Widdel \& Pfennig, 1984) and $1 \mathrm{ml} 0 \cdot 1 \%$ resazurin; $\mathrm{pH}$ was adjusted to $7 \cdot 2$ with $10 \mathrm{M} \mathrm{KOH}$. The basal medium was boiled under a stream of $\mathrm{O}_{2}$-free $\mathrm{N}_{2}$ gas and cooled to room temperature and $5 \mathrm{ml}$ aliquots were distributed in Hungate tubes under a stream of $\mathrm{O}_{2}$-free $\mathrm{N}_{2}$ gas. The $\mathrm{N}_{2}$ gas phase was replaced with $\mathrm{N}_{2} / \mathrm{CO}_{2}(80: 20, \mathrm{v} / \mathrm{v})$ and the tubes were autoclaved for $45 \mathrm{~min}$ at $110^{\circ} \mathrm{C}$. Prior to inoculation, $0 \cdot 1 \mathrm{ml} 2 \%$ $\mathrm{Na}_{2} \mathrm{~S} .9 \mathrm{H}_{2} \mathrm{O}, 0.1 \mathrm{ml} \quad 10 \% \mathrm{NaHCO}_{3}$ and $0.1 \mathrm{ml} 15 \%$ $\mathrm{MgCl}_{2} \cdot 6 \mathrm{H}_{2} \mathrm{O}$ were added. 
Table 1. Desulfovibrio strains isolated from Tunisian marine sediments

Desulfovibrio strain TBP-1, D. senezii DSM $8436^{\mathrm{T}}$ and D. alaskensis NCIMB $13491^{\mathrm{T}}$ were respectively described by Boyle et al. (1999), Tsu et al. (1998) and Feio et al. (2004).

\begin{tabular}{|lclc|}
\hline Strain & Substrate & Nearest phylogenetic relative & 16S rRNA gene sequence similarity (\%) \\
\hline MB2 & Peptone & Desulfovibrio TBP-1 & $99 \cdot 3$ \\
MB3 $^{\mathrm{T}}$ & $\mathrm{H}_{2}$ & D. senezii DSM $8436^{\mathrm{T}}$ & $91 \cdot 3$ \\
LB2 & Peptone & Desulfovibrio TBP-1 & $99 \cdot 3$ \\
LB3 & $\mathrm{H}_{2}$ & D. senezii DSM $8436^{\mathrm{T}}$ & $91 \cdot 3$ \\
LB2 & $\mathrm{H}_{2}$ & D. senezii DSM $8436^{\mathrm{T}}$ & $99 \cdot 9$ \\
LT3 & $\mathrm{H}_{2}$ & D. senezii DSM $8436^{\mathrm{T}}$ & $91 \cdot 3$ \\
KM2 & Peptone & D. senezii DSM 8436 & $93 \cdot 8$ \\
SIJ23 & Yeast extract & D. alaskensis NCIMB $13491^{\mathrm{T}}$ & $99 \cdot 7$ \\
\hline
\end{tabular}

Enrichments were performed in Hungate tubes containing $5 \mathrm{ml}$ medium and inoculated with sample diluted to $10 \%$. $\mathrm{H}_{2}+\mathrm{CO}_{2}\left[80: 20(\mathrm{v} / \mathrm{v}), 2\right.$ bar], peptone $\left(10 \mathrm{~g} \mathrm{l}^{-1}\right)$ or yeast extract $\left(0 \cdot 2 \mathrm{~g} \mathrm{l}^{-1}\right)$ were used as substrates. Acetate $(2 \mathrm{mM})$ was added as the carbon source in the presence of hydrogen as electron donor. The tubes were incubated at $30^{\circ} \mathrm{C}$ for 3 days. Three enrichment series were performed. Cultures were purified by repeated use of the Hungate roll-tube method with medium solidified with $2.5 \%(\mathrm{w} / \mathrm{v})$ agar (Difco). Several colonies that developed were picked and cultured in the corresponding culture medium. The process of isolation was repeated several times until isolates were deemed to be axenic. Physiological optimal growth conditions (for strain $\mathrm{MB}^{\mathrm{T}}$ only) were determined in duplicate experiments conducted in basal medium containing lactate $(20 \mathrm{mM})$ and thiosulfate $(20 \mathrm{mM})$ as described by Fardeau et al. (1993). Growth was measured by inserting tubes directly into a model Cary 50 Scan spectrophotometer (Varian) and measuring the $\mathrm{OD}_{580}$. Sulfide was determined photometrically as colloidal CuS following the method of Cord-Ruwisch (1985).

Genomic DNA was extracted according to the protocol described for the Wizard Genomic DNA purification kit (Promega). 16S rRNA genes were amplified by using primers Fd1 (5'-AGAGTTTGATCCTGGCTCAG-3') and Rd1 (5-AAGGAGGTGATCCAGCC-3') and by using the following reaction conditions: $1 \mathrm{~min}$ at $94^{\circ} \mathrm{C}, 30$ cycles of $30 \mathrm{~s}$ at $94^{\circ} \mathrm{C}, 1 \mathrm{~min}$ at $50^{\circ} \mathrm{C}$ and $2 \mathrm{~min}$ at $72{ }^{\circ} \mathrm{C}$, and a final extension step of $10 \mathrm{~min}$ at $72^{\circ} \mathrm{C}$. PCR fragments were then cloned into pGEM-T-easy (Promega). Recombinant clones, with inserts of the correct length, were sequenced by using primers SP6 (5'-ATTTAGGTGACACTATAGAA-3') and T7 (5'-TAATACGACTCACTATAGGG-3') (Genome Express). The nucleotide sequences of the $16 \mathrm{~S}$ rRNA genes were compared with reference sequences from the GenBank database (Benson et al., 1999). The $16 \mathrm{~S}$ rRNA gene sequence of strain $\mathrm{MB}^{\mathrm{T}}$ was aligned with reference sequences of various Desulfovibrio species using programs provided by the Ribosomal Database Project II (Maidak et al., 2001). Sequence alignment was verified manually using the program BIOEDIT (Hall, 1999). Positions of sequence and alignment uncertainty were omitted from the analysis. Pairwise evolutionary distances based on an unambiguous stretch of $1274 \mathrm{bp}$ were computed by using the Jukes \& Cantor (1969) method. The dendrogram was constructed by using the neighbour-joining method (Saitou \& Nei, 1987). Confidence in the tree topology was determined by bootstrap analysis based on 100 resamplings (Felsenstein, 1985).

Several SRB were isolated from marine sediments recovered near Tunis, Korbous and Bizerte in the presence of hydrogen, peptone or yeast extract as substrates and sulfate as the terminal electron acceptor. All isolates were found to be phylogenetically related to members of the genus Desulfovibrio (Table 1). Strains LB2 and MB2, isolated from marine sediments recovered near Bizerte, were found to be closely related ( $>99 \% 16 \mathrm{~S}$ rRNA gene sequence similarity) to an uncharacterized Desulfovibrio strain, TBP-1 (Boyle et al., 1999). Strain SIJ23, isolated from marine sediments recovered near Tunis, and strain LB4, isolated from marine sediments recovered near Bizerte, were

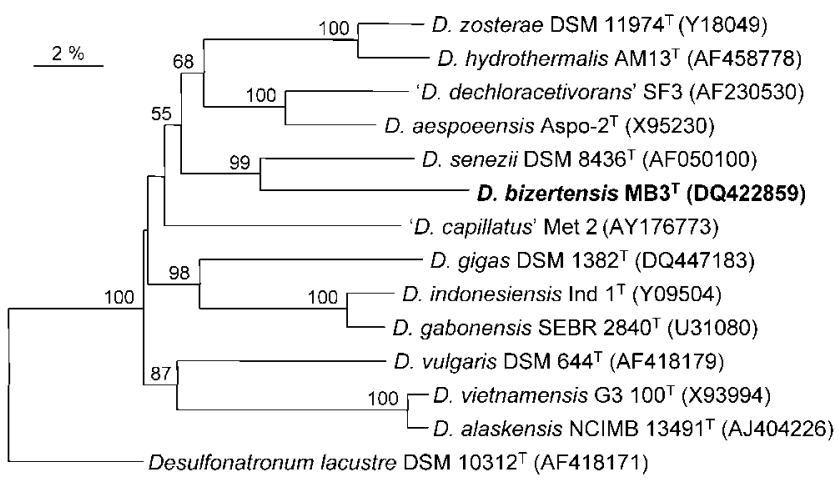

Fig. 1. Neighbour-joining phylogenetic dendrogram based on 16S rRNA gene sequence comparison indicating the position of strain $\mathrm{MB}^{\top}$ among the most closely related members of the genus Desulfovibrio. Desulfonatronum lacustre DSM $10312^{\top}$ was used as an outgroup. Bootstrap values based on 100 resamplings are given at nodes. Bar, $2 \%$ sequence divergence. 
phylogenetically related $(99-100 \%$ similarity $)$ to Desulfovibrio alaskensis and Desulfovibrio senezii, respectively (Feio et al., 2004; Tsu et al., 1998). Four other strains isolated from marine sediments recovered near Korbous (strain KM2), Bizerte (strains LB3 and $\mathrm{MB}^{\mathrm{T}}$ ) and Tunis (strain LT3) also had D. senezii as their closest phylogenetic relative, but with low $16 \mathrm{~S}$ rRNA gene sequence similarity $(<97 \%)$, indicating that they may represent novel species of the genus Desulfovibrio. Only strain $\mathrm{MB}^{\mathrm{T}}$ was characterized further.

Strain $\mathrm{MB}^{\mathrm{T}}$ was strictly anaerobic and mesophilic; optimal temperature for growth was $40^{\circ} \mathrm{C}$ (range $15-45^{\circ} \mathrm{C}$ ). For $\mathrm{pH}$ studies, the medium was adjusted to the desired $\mathrm{pH}$ using anaerobically prepared stock solutions of $\mathrm{NaHCO}_{3}(10 \%)$ or $\mathrm{Na}_{2} \mathrm{CO}_{3}(10 \%)$. Strain $\mathrm{MB}^{\mathrm{T}}$ was neutrophilic; the optimum $\mathrm{pH}$ for growth was 7 and growth occurred between $\mathrm{pH} 6 \cdot 0$ and $8 \cdot 1$. For determination of $\mathrm{NaCl}$ requirements, $\mathrm{NaCl}$ was weighed directly in the tubes at concentrations of $0-130 \mathrm{~g} \mathrm{l}^{-1}$ before dispensing to $\mathrm{NaCl}-$ free basal medium. The isolate was slightly halophilic and grew in the presence of $\mathrm{NaCl}$ concentrations ranging from 5 to $50 \mathrm{~g} \mathrm{l}^{-1}$, with optimum growth at $20 \mathrm{~g} \mathrm{l}^{-1}$.

The following substrates $(20 \mathrm{mM})$ were used as carbon and energy sources: lactate, ethanol, pyruvate, malate, fumarate, succinate, $\mathrm{H}_{2} / \mathrm{CO}_{2}$ with acetate $(2 \mathrm{mM})$, butanol and propanol. Acetate, propionate, butyrate, Casamino acids $(0 \cdot 1 \%)$, fructose, glucose and methanol $(40 \mathrm{mM})$ were also tested but did not support growth. Sulfate $(20 \mathrm{mM})$, thiosulfate $(20 \mathrm{mM})$, elemental sulfur $(0 \cdot 1 \%)$, sulfite $(2 \mathrm{mM})$ and fumarate $(20 \mathrm{mM})$ were used as terminal electron acceptors, but not nitrate $(20 \mathrm{mM})$ or nitrite $(2 \mathrm{mM})$. Strain $\mathrm{MB}^{\mathrm{T}}{ }^{\mathrm{f}}$ fermented pyruvate into acetate, hydrogen and $\mathrm{CO}_{2}$. Fumarate was fermented only weakly. Fermentation products were determined as described by
Fardeau et al. (1993). The end products from lactate metabolism in the presence of thiosulfate as terminal electron acceptor were acetate, $\mathrm{CO}_{2}$ and $\mathrm{H}_{2} \mathrm{~S}$.

Growth of strain $\mathrm{MB}^{\mathrm{T}}$ was inhibited by the addition of chloramphenicol $\left(50 \mu \mathrm{g} \mathrm{ml}^{-1}\right)$, ampicillin $\left(100 \mu \mathrm{g} \mathrm{ml}^{-1}\right)$ and vancomycin $\left(300 \mu \mathrm{g} \mathrm{ml}^{-1}\right)$.

The presence of bisulfite reductase (desulfoviridin) was confirmed by measuring the absorbance of cell-free extracts at $630 \mathrm{~nm}$ (Badziong et al., 1978). In addition, $c$-type cytochromes were detected by reduction of extracts with sodium dithionite, with two peaks occurring at 418 and $550 \mathrm{~nm}$.

The $\mathrm{G}+\mathrm{C}$ content of the DNA (determined by the Identification Service of the DSMZ, Braunschweig, Germany) was $51 \mathrm{~mol} \%$ based on the method of Mesbah et al. (1989).

Analysis of the almost complete sequence (1274 bp) of the $16 \mathrm{~S}$ rRNA gene of strain $\mathrm{MB}^{\mathrm{T}}$ revealed that it grouped with members of the family Desulfovibrionaceae, order Desulfovibriales, in the Deltapoteobacteria. The phylogenetic tree constructed is shown in Fig. 1. As indicated above, strain $\mathrm{MB} 3{ }^{\mathrm{T}}$ clustered with $D$. senezii DSM $8436^{\mathrm{T}}$, an isolate recovered from a solar saltern in California (Tsu et al., 1998), with a $16 \mathrm{~S}$ rRNA gene sequence similarity of $91 \cdot 3 \%$. Phenotypic differences were observed between strain $\mathrm{MB}^{\mathrm{T}}$ and $D$. senezii, including the range of substrates utilized, salt tolerance and DNA G $+\mathrm{C}$ content (Table 2). In addition to the taxonomic significance of strain $\mathrm{MB}^{\mathrm{T}}$ as a novel representative of the SRB within the Deltaproteobacteria, it is noteworthy that the enrichments described herein, performed with marine sediment samples originating from different locations in Tunisia, have led to the isolation of only Desulfovibrio-like strains when using

Table 2. Comparison of the morphological and physiological properties of strain $\mathrm{MB}^{\top}$ and D. senezii DSM $8436^{\top}$

Optimum values are given in parentheses. -, No growth; + , good growth. Data for D. senezii DSM $8436^{\mathrm{T}}$ were taken from Tsu et al. (1998).

\begin{tabular}{|c|c|c|}
\hline Characteristic & Strain $\mathrm{MB}^{\mathrm{T}}$ & D. senezii DSM $8436^{\mathrm{T}}$ \\
\hline Cell size $(\mu \mathrm{m})$ & $0 \cdot 5 \times 2 \cdot 0-3 \cdot 0$ & $0 \cdot 3 \times 1 \cdot 0-1 \cdot 3$ \\
\hline Temperature range for growth $\left({ }^{\circ} \mathrm{C}\right)$ & $15-45(40)$ & $25-45(37)$ \\
\hline $\mathrm{pH}$ range for growth & $6 \cdot 0-8 \cdot 1(7 \cdot 0)$ & $6 \cdot 4-8 \cdot 3(7 \cdot 6)$ \\
\hline Salinity range for growth $(\% \mathrm{w} / \mathrm{v} \mathrm{NaCl})$ & $0 \cdot 5-5 \cdot 0(2 \cdot 0)$ & $0-12 \cdot 5(2 \cdot 5)$ \\
\hline DNA G + C content $(\mathrm{mol} \%)$ & 51 & 62 \\
\hline \multicolumn{3}{|l|}{ Utilization of electron donors } \\
\hline Ethanol & + & - \\
\hline Fumarate & + & - \\
\hline Malate & + & - \\
\hline Cysteine & - & + \\
\hline Succinate & + & - \\
\hline Elemental sulfur as electron acceptor & + & - \\
\hline
\end{tabular}


hydrogen as the substrate. However, the prominent isolation of these Desulfovibrio strains may result from their known ability to grow rapidly when using hydrogen as substrate (Jørgensen \& Bak, 1991) as compared with the growth of other hydrogenotrophic SRB species. Interestingly, among the Desulfovibrio strains recovered from Tunisian marine sediments, we have isolated some using peptone as substrate, providing further evidence that SRB may play a decisive role in the regulation of electron flow in protein amino-acid turnover through sulfate reduction in marine ecosystems (Hansen \& Blackburn, 1995; Baena et al., 1998).

On the basis of its phenotypic, genotypic and phylogenetic characteristics, strain $\mathrm{MB}^{\mathrm{T}}$ is proposed as the type strain of a novel species, Desulfovibrio bizertensis sp. nov.

\section{Description of Desulfovibrio bizertensis sp. nov.}

Desulfovibrio bizertensis (bi.zer.ten'sis. N.L. masc. adj. bizertensis from Bizerte, referring to the place of isolation of the type strain).

Cells are Gram-negative, vibrio-shaped, motile, non-sporeforming rods, approximately $2 \cdot 0-3 \cdot 0 \mu \mathrm{m}$ in length and $0.5 \mu \mathrm{m}$ in diameter, and occur singly or in pairs. No spores are formed. Strictly anaerobic, mesophilic, neutrophilic and slightly halophilic. The temperature range for growth is $15-45^{\circ} \mathrm{C}$ (optimum $40^{\circ} \mathrm{C}$ ). The optimum $\mathrm{pH}$ is $7 \cdot 0$. Vitamins, biotrypcase and yeast extract are not required for growth. Strictly anaerobic. Reduces sulfate, sulfite, thiosulfate, elemental sulfur and fumarate. Nitrate and nitrite are not used as terminal electron acceptors. Substrates that are oxidized via sulfate reduction are lactate, ethanol, pyruvate, malate, fumarate, succinate, $\mathrm{H}_{2}$ plus acetate, butanol and propanol. Desulfoviridin-type bisulfite reductase and $c$-type cytochromes are present. The $\mathrm{G}+\mathrm{C}$ content of the DNA is $51 \mathrm{~mol} \%$.

The type strain, MB3 ${ }^{\mathrm{T}}\left(=\right.$ DSM $18034^{\mathrm{T}}=$ NCIMB $\left.14199^{\mathrm{T}}\right)$, was isolated from marine sediment recovered near Bizerte, Tunisia.

\section{Acknowledgements}

Many thanks are due to G. Fauque for suggested improvements to the manuscript.

\section{References}

Alazard, D., Dukan, S., Urios, A., Verhé, F., Bouabida, N., Morel, F., Thomas, P., Garcia, J.-L. \& Ollivier, B. (2003). Desulfovibrio hydrothermalis sp. nov., a novel sulfate-reducing bacterium isolated from hydrothermal vents. Int J Syst Evol Microbiol 53, 173-178.

Badziong, W., Thauer, R. K. \& Zeikus, J. G. (1978). Isolation and characterization of Desulfovibrio growing on hydrogen plus sulfate as the sole energy source. Arch Microbiol 116, 41-49.

Baena, S., Fardeau, M.-L., Labat, M., Ollivier, B., Garcia, J.-L. \& Patel, B. K. C. (1998). Desulfovibrio aminophilus sp. nov., a novel amino acid degrading and sulfate reducing bacterium from an anaerobic dairy wastewater lagoon. Syst Appl Microbiol 21, 498-504.

Bale, S. J., Goodman, K., Rochelle, P. A., Marchesi, J. R., Fry, J. C., Weightman, A. J. \& Parkes, R. J. (1997). Desulfovibrio profundus sp. nov., a novel barophilic sulfate-reducing bacterium from deep sediment layers in the Japan Sea. Int J Syst Bacteriol 47, 515-521.

Benson, D. A., Boguski, M. S., Lipman, D. J., Ostell, J., Ouellette, B. F. F., Rapp, B. A. \& Wheeler, D. L. (1999). GenBank. Nucleic Acids Res 27, 12-17.

Boyle, A. W., Phelps, C. D. \& Young, L. Y. (1999). Isolation from estuarine sediments of a Desulfovibrio strain which can grow on lactate coupled to the reductive dehalogenation of 2,4,6-tribromophenol. Appl Environ Microbiol 65, 1133-1140.

Campbell, L., Kasprzycki, M. A. \& Postgate, J. R. (1966). Desulfovibrio africanus sp. nov., a new dissimilatory sulfate-reducing bacterium. J Bacteriol 92, 1122-1127.

Cord-Ruwisch, R. (1985). A quick method for the determination of dissolved and precipitated sulfides in cultures of sulfate-reducing bacteria. J Microbiol Methods 4, 33-36.

Esnault, G., Caumette, P. \& Garcia, J.-L. (1988). Characterization of Desulfovibrio giganteus sp. nov., a sulfate reducing bacterium isolated from a brackish coastal lagoon. Syst Appl Microbiol 10, 147-151.

Fardeau, M.-L., Cayol, J.-L., Magot, M. \& Ollivier, B. (1993). $\mathrm{H}_{2}$ oxidation in the presence of thiosulfate, by a Thermoanaerobacter strain isolated from an oil-producing well. FEMS Microbiol Lett 113, 327-332.

Feio, M. J., Zinkevich, V., Beech, I. B., Llobet-Brossa, E., Eaton, P., Schmitt, J. \& Guezennec, J. (2004). Desulfovibrio alaskensis sp. nov., a sulphate-reducing bacterium from a soured oil reservoir. Int J Syst Evol Microbiol 54, 1747-1752.

Felsenstein, J. (1985). Confidence limits on phylogenies: an approach using the bootstrap. Evolution 39, 783-791.

Hall, T. A. (1999). BIOEDIT: a user-friendly biological sequence alignment editor and analysis program for Windows 95/98/NT. Nucleic Acids Symp Ser 41, 95-98.

Hansen, L. S. \& Blackburn, T. H. (1995). Amino acid degradation by sulfate-reduction bacteria: evaluation of four methods. Limnol Oceanogr 40, 502-510.

Hungate, R. E. (1969). A roll-tube method for the cultivation of strict anaerobes. Methods Microbiol 3B, 117-132.

Jørgensen, B. B. (1982). Mineralization of organic matter in the seabed - the role of sulfate reduction. Nature 269, 643-645.

Jørgensen, B. B. \& Bak, F. (1991). Pathways and microbiology of thiosulfate transformations and sulfate reduction in a marine sediment (Kattegat, Denmark). Appl Environ Microbiol 57, 847-856.

Jukes, T. H. \& Cantor, C. R. (1969). Evolution of protein molecules. In Mammalian Protein Metabolism, vol. 3, pp. 211-232. Edited by H. N. Munro. New York: Academic Press.

Le Gall, J. (1963). A new species of Desulfovibrio. J Bacteriol 86, 1120.

Maidak, B. L., Cole, J. R., Lilburn, T. G. \& 7 other authors (2001). The RDP-II (Ribosomal Database Project). Nucleic Acids Res 29, 173-174

Mesbah, M., Premachandran, U. \& Whitman, W. B. (1989). Precise measurement of the $\mathrm{G}+\mathrm{C}$ content of deoxyribonucleic acid by high-performance liquid chromatography. Int J Syst Bacteriol 39, 159-167.

Reichenbecher, W. \& Schink, B. (1997). Desulfovibrio inopinatus, sp. nov., a new sulfate-reducing bacterium that degrades hydroxyhydroquinone (1,2,4-trihydroxybenzene). Arch Microbiol 168, 338-344.

Saitou, N. \& Nei, M. (1987). The neighbor-joining method: a new method for reconstructing phylogenetic trees. Mol Biol Evol 4, 406-425. 
Tsu, I. I., Huang, C., Garcia, J.-L., Patel, B. K. C., Cayol, J. L., Baresi, L. \& Mah, R. A. (1998). Isolation and characterization of Desulfovibrio senezii sp. nov., a halotolerant sulfate reducer from a solar saltern and phylogenetic confirmation of Desulfovibrio fructosovorans as a new species. Arch Microbiol 170, 313-317.

van der Maarel, M. J. E. C., van Bergeijk, S., van Werkhoven, A. F., Laverman, A. M., Meijer, W. G., Stam, W. T. \& Hansen, T. A. (1996). Cleavage of dimethylsulfoniopropionate and reduction of acrylate by Desulfovibrio acrylicus sp. nov. Arch Microbiol 166, 109-115.
Widdel, F. \& Hansen, T. (1992). The dissimilatory sulfate- and sulfurreducing bacteria. In The Prokaryotes, 2nd edn, vol. I, pp. 583-624. Edited by A. Balows, H. G. Trüper, M. Dworkin, W. Harder \& K. H. Schleifer. New York: Springer.

Widdel, F. \& Pfennig, N. (1981). Studies on dissimilatory sulfatereducing bacteria that decompose fatty acids. I. Isolation of new sulfate-reducing bacteria enriched with acetate from saline environments. Description of Desulfobacter postgatei gen. nov., sp. nov. Arch Microbiol 129, 395-400. 